\title{
Tanulmányok
}

\section{ANESZTEZIOLÓGIA ÉS INTENZÍV TERÁPIA - EGY FIATAL INTERDISZCIPLINÁRIS TUDOMÁNYÁG HAZAI HELYZETE ÉS JÖVŐKÉPE}

\section{ANESTHESIOLOGY AND INTENSIVE CARE: PRESENT STATE AND FUTURE PROSPECTS OF A YOUNG DISCIPLINE}

\author{
Fülesdi Béla \\ az EMMI Egészségügyi Szakmai Kollégiumának elnöke, Debreceni Egyetem Aneszteziológiai és Intenzív Terápiás Tanszék \\ fulesdi@med.unideb.hu
}

\section{ÖSSZEFOGLALÁS}

Az összeállítás célja a hazai aneszteziológiai betegellátás, oktatás és kutatás jelen helyzetének megítélése és a szakma előtt álló feladatok összefoglalása.

\section{ABSTRACT}

The aim of the work is to present an overview on the status of patient care, teaching and research in the field of anesthesiology and intensive care.

Kulcsszavak: betegellátás, kutatás, aneszteziológia

Keywords: patient care, research, anesthesiology

Mi, a szakma müvelői, azzal szoktunk tréfásan büszkélkedni a sebész kollégáknak: írásos bizonyítékkal rendelkezünk arról, hogy az anesztézia volt a legelső orvosi diszciplína. Mózes 1. könyvében, a teremtésről szóló fejezetben ugyanis ez áll: „Bocsáta tehát az Úr Isten mély álmot az emberre, és ez elaluvék. Akkor kivőn egyet annak oldalbordái közül, és hússal tölté be annak helyét" (1Móz, 2,21). A tudatosan, szervezett keretek között végzett anesztéziára 1846. október 16-ig kellett várnia az orvostudománynak, Bostonban, a Massachusetts General Hospitalban ekkor végezték az első éternarkózist. További, már hazai jelentőségü orvostörténeti érdekesség, hogy pár hónappal később, 1847. január 11-én Balassa János a Szent Rókus Kórházban szintén éternarkózisban operált. 
Az aneszteziológia és intenzív terápia relatíve fiatal diszciplína, hazánkban az '50-es évek közepe-vége felé kezdett kialakulni, és rálépni a szakmai önállóság útjára. Minden szakma fejlődésének vannak megkerülhetetlen fázisai, amelyeken át kell esnie: az önálló szakmai keretrendszer kialakítása az 1950-es évek végére, az 1960-as évek elejére tehető. Ezt követően, a tanulási-tapasztalatszerzési fázisban szakmánk müvelői külföldi konferenciákon és tanulmányutakon sajátították el a diszciplína fortélyait, ismerkedtek a folyamatosan modernizálódó eszközrendszerrel és módszerekkel, és meghonosították azokat a hazai gyakorlatban. A '70-es években már egy komoly utánpótlásképzési fázis indulhatott be, amelynek zászlóshajói az orvosképző egyetemek mellett az Orvostovábbképző Egyetem és a megyei kórházak voltak. A sebészi szakmák fejlődése, az egyre súlyosabb társbetegséggel rendelkezők sebészi ellátásnak igénye nemcsak a szakmai instrumentárium fejlődését vonta maga után, hanem egyre meghatározóbb volt az utánpótlásképzéssel szembeni fokozott igény is. Az egyetemeken önálló tanszékek és szakképzési grémiumok jöttek létre (utoljára a Debreceni Egyetemen 1999-ben), amelyek már regionális szinten, rendszerezetten kezdték meg a szakember-utánpótlás képzését, a tudományos tevékenységet, és indították be a graduális képzést. Lassan egy évtizede az Európai Aneszteziológiai Akadémia által kialakított, nemzetközi akkreditációjú szakvizsgáztatási tesztsor képezi a belépőt a hazai szakvizsgához és a hazánkban szerzett szakképesítéseket az EU szinte valamennyi országában elfogadják.

Miért írtam le ezeket a fejlődési fázisokat ilyen részletességgel egy, az MTA részére készített, elsősorban a tudományos aktivitást összefoglalni kívánó beszámolóban? Azért, mert érzékeltetni szerettem volna, hogy a rendszerezett, klinikai kérdésfelvetéseken alapuló szakterületi kutatásnak elengedhetetlen előfeltétele egy biztonságos szakmai keretrendszer kialakulása és az utánpótlás képzésének megteremtése. Hála szakmánk áldozatkész első generációjának, akik ezeket a kezdeti lépéseket megtették, 2006-ban a szakma tízéves fejlesztési koncepciójának kidolgozásakor már külön fejezetet szentelhettünk annak, hogy az egyes aneszteziológiai és intenzív terápiás kutatómühelyek hogyan tudják tevékenységüket koordinálni, és hogyan tudnak hozzájárulni az egyetemi doktori minősítéssel rendelkező vezetők kineveléséhez (Aneszteziológiai és Intenzív Terápiás Szakmai Kollégium, 2006). Egyre hangsúlyosabb célként jelenik meg az is, hogy hazánk szakmai kutatásai jelen legyenek a nemzetközi szakmai közéletben is.

A szakmánk nemzetközi tudományos megítélését számos meghatározó honfitársunk alapozta meg. A külföldre szakadt szakemberek nevei között Földes Ferenc, Ágoston Sándor, Tassonyi Edömér, Nemes Csaba neve mindenképpen említésre méltó. Hazai viszonylatban az aneszteziológia és intenzív terápia területén négy MTA doktora minősítésü szakember van: Tassonyi Edömér, Pénzes István, Bogár Lajos és Fülesdi Béla. Meg kell említeni, hogy 2000 óta szakterületünkön negyvennégy egyetemi doktori $(\mathrm{PhD})$ fokozatszerzés történt, ami egyenletesen, folyamatosan emelkedő trendet mutat. 
Az egyes egyetemek doktori iskoláival párhuzamosan létrejöttek az egyetemi tanszéki kutatómühelyekhez kapcsolódó PhD-programok is, és a regisztrált vezető oktatók száma dinamikus emelkedést mutat. A Semmelweis Egyetem, a Pécsi és a Szegedi Tudományegyetem aneszteziológiai intézetei az illető egyetemek klinikai orvostudományi doktori iskoláiban, a Debreceni Egyetem Aneszteziológiai Klinikája pedig az egyetem Idegtudományi Doktori Iskolájában végzi tevékenységét. Azt gondolom, érdemes felsorolásszerüen ismertetni az egyes intézetek főbb kutatási irányait, hiszen ebből képet kaphatunk, milyen széles palettán mozog a hazai aneszteziológiai és intenzív terápiás kutatás.

\section{Semmelweis Egyetem, Budapest:}

- szepszis, szepszisgenetika, nozokomiális fertőzések;

- szívsebészeti anesztézia, szívsebészeti mütétek nem kardiális rizikófaktorai, pszichológiai tényezők hatása a kimenetelre;

- hemodinamikai vizsgálatok gyermekkori szívmütétek után;

- miokardium protekció;

- pozitív szuggesztiók az intenzív osztályos kimenetelre;

- etikai kérdések vizsgálata újraélesztés, illetve életvégi döntések kapcsán;

- UH-vezérelt regionális anesztézia;

- állatkísérletek szepszisben (hiperoxia, vazopresszin), vérzéses sokkban (iv. szulfid), iszkémia/reperfúzió.

\section{Szegedi Tudományegyetem AITK:}

- szepszis: biomarkerekkel kapcsolatos kutatás, antibiotikum-terápia;

- vérzés reszuszcitáció: reszuszcitációs végpontok (állatkísérletek és klinikai vizsgálatok);

- perioperatív intenzív terápia: magasabb szintü hemodinamikai monitorozás és a posztoperatív szövődmények csökkentése;

- lélegeztetés: alveolus toborzás spontán légző betegekben;

- folyadékterápia: krisztalloid-kolloid reszuszcitáció hemodinamikai hatásai.

\section{Pécsi Tudományegyetem AITK:}

- a szepszis és a szeptikus sokk okozta hemodinamikai és hemoreológiai változások vizsgálata;

- a mikropartikulumok diagnosztikai alkalmazása a szepszis kórfolyamatának elörejelzésében;

- a fájdalomcsillapítás farmakológiája;

- a pulmonális embólia terápiájához kapcsolódó hemosztázis változások;

- a bakteriális faktorok (adherencia) szerepe a perioperatív nozokomiális infekciók kialakulásában;

- új farmakológiai stresszteszt az agyi perfúziós zavarok diagnosztikájában;

- a vér maximális oxigénszállító kapacitásának keresése hemoreológiai módszerekkel. 


\section{Debreceni Egyetem AITK:}

- neuroanesztézia és neurointenzív: cerebrális hemodinamikai vizsgálatok, szubarachnoideális vérzés hemodinamikai kezelése, Tako-Tsubo-kardiomiopátia SAV-ban;

- fájdalomkutatás: preemptív és preventív analgézia: experimentális vizsgálatok és klinikai vizsgálatok idegsebészeti és mellkassebészeti betegekben;

- neuromuszkuláris kutatás: experimentális vizsgálatok (frenikusz-diafragma modell), új reverzáló szer fejlesztése, klinikai neuromuszkuláris kutatások, új neuromuszkuláris monitor fejlesztés;

- mellkassebészeti anesztézia: optimális lélegeztetési stratégia vizsgálata egytüdős lélegeztetésben;

- szívsebészeti anesztézia: rizikóbecslés a szívsebészetben;

- szepszis: experimentális modell (szeptikus enkefalopátia, valamint hemodinamikai és hemoreológiai vizsgálatok), klinikai vizsgálatok: szeptikus enkefalopátia;

- anesztéziamélység-monitorozás: klinikai vizsgálatok;

- szuggesztiók alkalmazása anesztézia során;

- a mútős személyzet anesztetikum expozíciójának vizsgálata.

\begin{tabular}{|c|c|c|}
\hline Rank & Full Journal Title & $\begin{array}{c}\text { Journal } \\
\text { Impact } \\
\text { Factor }\end{array}$ \\
\hline 1 & Lancet Respiratory Medicine & 15.328 \\
\hline 2 & American Journal of... & 13.118 \\
\hline 3 & Intensive Care Medicine & 10.125 \\
\hline 4 & Critical Care Medicine & 7.422 \\
\hline 5 & Chest & 6.136 \\
\hline 6 & Resuscitation & 5.414 \\
\hline 7 & Critical Care & 4.950 \\
\hline 8 & Annals of Intensive Care & 4.529 \\
\hline 9 & Journal of Neurotrauma & 4.377 \\
\hline 10 & Critical Care and Resuscitation & 3.317 \\
\hline 11 & Journal of Intensive Care & 3.262 \\
\hline 12 & Shock & 3.048 \\
\hline 13 & Human Gene Therapy Clinical... & 2.889 \\
\hline 14 & Journal of Trauma and Acute Care & 2.802 \\
\hline 15 & Current Opinion in Critical Care & 2.706 \\
\hline 16 & Pediatric Critical Care Medicine & 2.659 \\
\hline 17 & Neurocritical Care & 2.488 \\
\hline 18 & Journal of Critical Care & 2.445 \\
\hline 19 & Seminars in Respiratory... & 2.274 \\
\hline 20 & Anasthesiologie \& ... & 2.055 \\
\hline 21 & American Journal of. . & 2.053 \\
\hline 22 & Minerva Anestesiologica & 2.036 \\
\hline 23 & Respiratory Care & 1.922 \\
\hline 24 & Injury-International & 1.910 \\
\hline 25 & Burns & 1.904 \\
\hline 26 & Critical Care Clinics & 1.782 \\
\hline 27 & Australian Critical Care & 1.479 \\
\hline 28 & Therapeutic Hypothermia and ... & 1.415 \\
\hline 29 & Critical Care Nurse & 1.333 \\
\hline 30 & Anaesthesia and .... & 1.283 \\
\hline 31 & Medicina Intensiva & 1.193 \\
\hline 32 & Journal of Trauma Nursing & 0.556 \\
\hline 33 & Anasthesiologie & 0.325 \\
\hline
\end{tabular}

\begin{tabular}{|c|c|c|}
\hline Rank & Full Journal Title & $\begin{array}{l}\text { Journal } \\
\text { Impact } \\
\text { Factor }\end{array}$ \\
\hline 1 & British Journal of Anaesthesia & 5.616 \\
\hline 2 & Pain & 5.557 \\
\hline 3 & Anesthesiology & 5.555 \\
\hline 4 & Anesthesia and Analgesia & 3.827 \\
\hline 5 & Anaesthesia & 3.794 \\
\hline 6 & European Journal of Anaesthesiology & 3.634 \\
\hline 7 & Regional Anesthesia and Pain Medicine & 3.459 \\
\hline 8 & Pain Physician & 3.407 \\
\hline 9 & European Journal of Pain & 2.900 \\
\hline 10 & Journal of Neurosurgical Anesthesiology & 2.828 \\
\hline 11 & Clinical Journal of Pain & 2.712 \\
\hline 12 & Pain Practice & 2.317 \\
\hline 13 & $\begin{array}{r}\text { Canadian Journal of Anesthesia/Journal canadien } \\
\text { d'anesthésie }\end{array}$ & 2.139 \\
\hline 14 & Pediatric Anesthesia & 2.082 \\
\hline 15 & Anasthesiologie \& Intensivmedizin & 2.055 \\
\hline 16 & Acta Anaesthesiologica Scandinavica & 2.049 \\
\hline 17 & International Journal of Obstetric Anesthesia & 2.040 \\
\hline 18 & Minerva Anestesiologica & 2.036 \\
\hline 19 & Current Opinion in Anesthesiology & 1.916 \\
\hline 20 & Journal of Clinical Monitoring and Computing & 1.819 \\
\hline 21 & Journal of Cardiothoracic and Vascular Anesthesia & 1.519 \\
\hline 22 & Journal of Anesthesia & 1.343 \\
\hline 23 & BMC Anesthesiology & 1.320 \\
\hline 24 & Journal of Clinical Anesthesia & 1.284 \\
\hline 25 & Anaesthesia and Intensive Care & 1.283 \\
\hline 26 & Anaesthesist & 0.964 \\
\hline 27 & Annales Françaises d'Anesthésie et de réanimation & 0.917 \\
\hline 28 & Schmerz & 0.894 \\
\hline 29 & Revista Brasileira de Anestesiologia & 0.517 \\
\hline 30 & Schmerztherapie & 0.325 \\
\hline
\end{tabular}

Forrás: Thomson Reuters impaktfaktor adatbázisa 
Ami a publikációs aktivitást illeti, a szakma hazai mühelyei az elmúlt tíz esztendőben egyre hangsúlyosabban jelentek meg a rangosabb folyóiratokban. Az ábrán azt mutatjuk be, hogy az aneszteziológiai és intenzív terápiás folyóiratok közül melyekben jelent meg hazai affiliációjú közlemény. (Az egyes folyóiratok melletti nyilak esetenként több közleményt is jelölhetnek.)

Megállapítható, hogy szakmánk mindkét szubdiszciplinájában jelentek meg a Q1 rangsorú folyóiratokban a szakma hazai képviselői által készült vizsgálatok.

\section{AZ ANESZTEZIOLÓGIAI KUTATÁS NEMZETKÖZI ÉS HAZAI JELLEMZŐI}

Nagyjából tíz esztendővel ezelőtt szakmánk vezető folyóiratában, az Anesthesiologyban egy elemzés jelent meg, amely arra mutatott rá, hogy az aneszteziológiai szakma tudományos aktivitása (az USA-ban) a családorvoslás mellett a legalacsonyabb. A szerzők, Debra A. Schwinn és Jeffrey R. Balser (2003) kritikusan igyekeztek feltárni a jelenség hátterét, és több dologra is rámutattak: az USA-ban egy közelmúltban végzett elemzés szerint az aneszteziológusok bére a Bureau of Labor Statistics adatai szerint (2013) az összes szakma vonatkozásában a legmagasabb (240 000 USD/év átlagos bér), messze meghaladva akár a számítógépes és információs iparban dolgozók, de az ipari vagy banki menedzserek jövedelmét is. A szerzők szerint ez a magas jövedelem valószínüleg elkényelmesíti a szakma kutatási aktivitását. Másrészt, az amerikai jogrendszerben a klinikai kutatások engedélyezése és következményesen annak kezdeményezése szintén korlátot szab a jelentős kutatási aktivitásnak. Ennek ellenére egy 2017-ben megjelent elemzés szerint az aneszteziológiai tudományos közlemények meghatározó része továbbra is az USA-ból származik (1995 és 2014 között közel 18000 közlemény), és Németországgal, az Egyesült Királysággal, Japánnal és Franciaországgal együtt az első öt országban szerepelnek (9500-6300-4600-4300/év közleményszámmal).

Magyarországon a helyzet egészen más. A magasabb potenciális jövedelem miatt a külföldi munkahelyek (elsősorban Anglia, Németország, Svájc) vonzereje nagy, ezáltal a nyelveket beszélő szakemberek elvándorlása a szakmánkban elég hangsúlyosnak mondható. A jelenlegi jövedelemviszonyok mellett az itthon maradó kollégák jelentős része másodállásban egészíti ki jövedelmét, így a tudományos tevékenységre ebben a kiégésre amúgy is fokozottan veszélyeztetett szakmában természetes módon kisebb energia jut.

Ami azonban reménykedésre adhat okot, hogy a hazai aneszteziológiai kutatómühelyekben egyre több TDK-hallgató, és egyre több rezidens, illetve fiatal szakorvos tevékenykedik a klinikai kutatás területén. Meggyőződésünk és tapasztalatunk is, hogy a klinikai kutatás hasznos védelmi technika a kiégés ellen és a fiatal kollégák visszatartásáért. A fiatalok bevonása a klinikai kutató- 
tevékenységbe tovább mélyíti a szakmai ismereteket, a kritikus gondolkodást, a nemzetközi irodalmi adatok ismeretét. Minden, a napi tevékenységben felvetődő tudományos kérdés vizsgálata abba az irányba hat, hogy növekedjen kollégáink kreatív problémamegoldó gondolkodása, ráadásul a klinikai kutatásban való részvétel változatosabbá teszi az egyhangú mindennapi munkát.

Összefoglalva: Az aneszteziológia és intenzív terápia egy relatíve fiatal önálló interdiszciplináris tudományág. Az utóbbi tíz esztendőben elkezdődött kedvező fejlődési trendet folytatva külön energiát kell fordítanunk az egyes kutatómühelyek közötti és az interdiszciplináris kutatótevékenység fejlesztésére, a pályázati források tudatos kihasználására és a nemzetközi tudományos kapcsolataink szélesítésére. Azt gondolom, hogy a szakma jelenleg vezető pozíciót betöltő kutatói előtt megvalósítható feladatként jelentkezik egy minél igényesebb és szélesebb fiatal kutatói generáció kinevelése, amely az amplifikáció törvényszerüségei szerint biztató jövőt vetít előre a hazai aneszteziológiai és intenzív terápiás kutatói tevékenység számára.

\section{IRODALOM}

Aneszteziológiai és Intenzív Terápiás Szakmai Kollégium (2006): Az aneszteziológia és intenzív terápia hosszú távú (10 éves) fejlesztési programja.

Bureau of Labor Statistics (2013): May 2013 National Occupational Employment and Wage Estimates United States. https://www.bls.gov/oes/2013/may/oes_nat.htm

Chen, S. Y. et al. (2017): Trend of Academic Publication Activity in Anesthesiology: A 2-decade Bibliographic Perspective. Asian Journal of Anesthesiology (Acta Anaesthesiologica Taiwanica), 55, 1, 3-8. DOI: 10.1016/j.aat.2016.06.005, https://goo.gl/qD5hsX

Schwinn, D. A. - Balsern J. R. (2003): Anesthesiology Physician Scientist in Academic Medicine. A Wake up Call. Anesthesiology, 104, 1, 170-178. https://www.ncbi.nlm.nih.gov/pmc/articles/ PMC2322866/ 